\title{
TINDAK TUTUR MEMUJI DALAM FILM KAZE TACHINU
}

\author{
Nimatul Maulida
}

\author{
312201500567@mhs.dinus.ac.id \\ Universitas Dian Nuswantoro
}

\begin{abstract}
This study aims to describe the use of Japanese compliment expression in Kaze Tachinu's movie. It includes the types of compliment, the forms of expression and the categories of compliment topics. The data of this study were taken from the utterances of characters which contain compliment expressions. The type of compliment expression, which are bound and unbound compliments, were then analyzed based on Yuan's theory. The forms of compliment expressions were analyzed based on the theories of Huang and Tseng, and the topic of compliment was analyzed by using Holmes's theory. This type of research is descriptive qualitative research with a pragmatic approach. The results of the study found 2 types of unbound compliments, they were direct and indirect compliment, each of which got 4 topics. And then for the bound compliment, there were found 13 expressive of compliments that consist of realization to complimenting directly and complimenting indirectly. Expressive forms of compliment in indirect compliment were found to be 11 forms, they are surprise, explanation, evaluation, knowing, offering reward, contrast, assumption, admiration, appreciation, request and pleasing. Direct compliment are very varied with the existence of evaluative markers, which are vocabulary that has the same meaning.
\end{abstract}

Keywords : Compliment Topics, Expression, Expressive form of Compliment, Pragmatics, Type of Compliment

Pragmatik adalah cabang ilmu linguistik yang mempelajari hubungan antara konteks dan makna. Menurut pendapat Yule (2014: 3) bahwa pragmatik adalah studi tentang makna yang disampaikan oleh penulis (penutur) dan ditafsirkan oleh pendengar (petutur). Levinson dalam Saifudin (2005:13) juga menyatakan bahwa pragmatik merupakan kajian ilmu yang mempelajari relasi-relasi antar bahasa dengan konteks tuturan. Hal yang penting dalam pragmatik yang dijabarkan oleh Saifudin (2018:111) yaitu pengguna bahasa, penggunaan bahasa, dan konteks. Ilmu pragmatik dalam Saifudin (2018:111) adalah membahas maksud penutur dalam tuturan yang digunakan, bukan membahas makna tuturan atau kalimat. Saifudin (2018:111)

\footnotetext{
${ }^{*}$ Artikel Skripsi Fakultas Ilmu Budaya Universitas Dian Nuswantoro
} 
Nimatul Maulida, Tindak Tutur Memuji dalam Film Kaze Tachinu

menjelaskan bahwa dalam pragmatik, tuturan atau teks menjadi tidak bermakna tanpa adanya konteks. Saifudin (2018:111) juga menjabarkan pengertian konteks yaitu, suatu kerangka konseptual berkenaan atas segala sesuatu yang dijadikan acuan dalam bertutur ataupun memahami maksud tuturan. Kerangka yang dimaksud oleh Saifudin (2018:111) yaitu seperangkat hubungan yang menjadi bagian dari pembentuk makna. Konteks berada dalam pikiran seseorang, yang berisi tentang pengetahuan atau informasi dasar dalam memahami tuturan atau bertutur (Saifudin, 2018:116).

Memuji merupakan tuturan ekspresif, karena dengan seseorang memuji, seseorang tersebut mengekspresikan rasa kagumnya saat melihat, merasakan atau menyikapi sesuatu. Kata memuji berasal dari kata puji, pujian menurut Holmes (1986: 485-486) yaitu merupakan suatu tuturan yang memiliki nilai yang baik untuk seseorang. Tuturan pujian dapat diucapkan secara tidak langsung maupun secara langsung. Holmes (1986: 496) mengklasifikasikan bentuk pujian ke dalam 4 jenis topik yaitu, pujian terhadap kepribadian, pujian terhadap kemampuan, pujian terhadap penampilan dan pujian terhadap kepemilikan benda lawan tutur.

Penelitian ini sangat penting diketahui dalam rangka membina hubungan sosial khususnya untuk pemelajar bahasa Jepang dengan mengetahui penggunaan ungkapan memuji. Sehingga pemelajar bahasa Jepang dapat menuturkan pujian dalam bahasa Jepang secara baik dan benar. Fenomena memuji pun dapat ditemukan dan dapat dipelajari dalam film Kaze Tachinu, sehingga peneliti ingin mengungkap bentuk ungkapan pujian yang diperoleh dalam film tersebut. Ruang lingkup penelitian berupa ungkapan pujian bahasa Jepang yang dituturkan oleh semua tokoh orang Jepang dalam film Kaze Tachinu.

\section{METODE PENELITIAN}

\section{Sumber Data}

Sumber data yang digunakan pada penelitian ini adalah film Kaze Tachinu karya Hayao Miyazaki. yang mempunyai tuturan-tuturan pujian bahasa Jepang. Sumber data dipilih karena dalam film tersebut terdapat berbagai bentuk ungkapan pujian yang antar percakapan memiliki makna tuturan pujian yang berbeda. 
Pemilihan dan pembatasan ini dengan mempertimbangkan faktor kecukupan dan variasi ungkapan pujian yang terdapat dalam sumber data.

\section{Satuan Analisis}

Data dalam penelitian ini berupa dialog yang digunakan oleh semua tokoh orang Jepang dalam film Kaze Tachinu yang memiliki tuturan memuji dalam bahasa Jepang.

\section{Teknik Pengumpulan Data}

Teknik pengumpulan data dalam penelitian ini adalah

1. Menonton film Kaze Tachinu ;

2. Menyimak dan mentranskrip tuturan semua tokoh Jepang dalam film Kaze Tachinu;

3. Memilah tuturan yang mengandung tuturan pujian langsung dan tidak langsung;

4. Mengkategorisasikan ungkapan pujian berdasarkan topik pujian dari teori Holmes;

5. Mengkategorisasikan jenis ungkapan pujian berdasarkan pujian terikat dan tidak terikat.

\section{Teknik Analisis Data}

Data yang dianalisis berdasarkan topik tuturan pujian oleh Holmes dan pembagian bentuk pujian terikat, tidak terikat oleh Yuan. Beberapa tahapan yang penulis lakukan dalam analisis data adalah sebagai berikut:

1. Menjabarkan konteks tiap-tiap data yang berupa potongan dialog berdasarkan pengertian konteks dari Leech;

2. Menentukan bentuk ungkapan pujian dengan menggunakan teori Yuan (2002:192) pembagian yaitu Unbound Semantic Formulas (Formula Semantik yang tidak terikat) dan Bound Semantic formulas (Formula semantik yang terikat); 
Nimatul Maulida, Tindak Tutur Memuji dalam Film Kaze Tachinu

3. Menentukan 14 bentuk ungkapan pujian tidak langsung berdasarkan penelitian Huang dan Tseng (2014:26) yaitu request, contras, explanation, assumption, want statement, evaluation, joke, admiration, reward offering, knowing, appreciation, pleasing, future expectation, dan surprise.

Pemaparan hasil analisis yang disajikan secara deskriptif. Hasil dari penelitian ini adalah sebuah paparan mengenai berbagai bentuk ungkapan pujian apa yang digunakan tokoh laki-laki Jepang maupun perempuan Jepang dalam film Kaze Tachinu.

\section{HASIL DAN PEMBAHASAN}

Data diperoleh berdasarkan topik pujian menurut teori Holmes (1986: 496) yang memiliki 4 topik pujian yaitu pujian terhadap kemampuan seseorang, pujian terhadap benda milik orang lain/kepemilikan barang, pujian terhadap pakaian/penampilan, dan pujian terhadap kepribadian/keramahan. Data dijabarkan konteks situasi tutur sehingga mengetahui latar belakang dari tuturan pujian.

Kemudian data dianalisis dengan menggunakan teori Yuan (2002:192) yaitu Formula semantik tidak terikat meliputi pujian langsung dan tidak langsung. Serta Formula semantik yang terikat yang terwujud dari kombinasi pujian langsung dan pujian tidak langsung. Berdasarkan penelitian Huang dan Tseng (2014:26) didapatkan 11 kategori yang memiliki bentuk ungkapan pujian tidak langsung yaitu request, contrast, explanation, assumption, evaluation, admiration, reward offering, knowing, appreciation, pleasing, dan surprise.

\section{1) Pujian Tidak Terikat}

\section{a) Pujian Langsung}

\section{Pada Topik Pujian Terhadap Penampilan}

Data $1(01.45 .00)$

Jiroo (14) : きれいだよ

"kirei da yo"

'kau terlihat cantik' 


\section{Konteks Data 1}

Partisipan dalam data 1 terjadi antara Jiroo dan Naoko. Hubungan antara Jiroo dengan Naoko adalah calon suami-calon istri. Percakapan ini terjadi pada malam hari di kediaman keluarga Kurokawa sebagai tempat persembunyian sementara Jiroo dari pihak pemerintah. Naoko meninggalkan sanatorium (tempat rehabilitasi untuk penderita tuberculosis) yang berada di pegunungan untuk menemui Jiroo. Dan saat itu juga mereka berdua memutuskan untuk menikah malam itu juga. Jiroo melihat Naoko yang mengenakan pakaian pernikahan dan merasa kagum dan senang

\section{Analisis}

Dalam tuturan data (1) Jiroo menyatakan pujian terhadap tampilan Naoko yang mengenakan pakaian pengantin yang merupakan pujian yang dituturkan secara langsung, terdapat pada kalimat "kirei da yo" terdapat kata "kirei" menurut kokugojiten (https://www.weblio.jp/content/\%E3\%81\%8D\%E3\%82\%8C\%E3\%81\% 84) yang berarti 目に見て美しく心地よいさま。美麗 (me ni mite utsukushiku kokochiyoi sama. birei) yaitu indah dan enak dipandang, kecantikan. Dan kemudian "kirei" termasuk dalam golongan kata sifat na. Pada tuturan tersebut menuturkan pujian terhadap penampilan petutur yang mengenakan pakaian pernikahaan yang indah dan juga memuji wajah cantik penutur.

\section{b) Pujian Tidak Langsung}

\section{Pada Topik Pujian Terhadap Kemampuan}

Data $2(01.47 .22-01.47 .25)$

Jiroo (2) : お医者さんになったんのね、おめでとう

"o isha san ni nattan no ne, omedetou”

'Selamat sudah menjadi dokter'

\section{Konteks Data 2}

Partisipan dalam data (2) terjadi antara Jiroo dan Kayo. Mereka adalah kakal dan adik yang akrab. Jiroo sebagai kakak, dan Kayo sebagai adik. Percakapan terjadi pada malam hari di ruang tamu kediaman keluarga Kurokawa saat Kayo berkunjung untuk menemui kakaknya yang telah menikah. Kayo menunggu kepulangan Jiroo yang bekerja sampai larut malam. Jiroo menyatakan lupa bahwa Kayo datang 
Nimatul Maulida, Tindak Tutur Memuji dalam Film Kaze Tachinu

berkunjung dan Jiroo memulai memberi selamat kepada Kayo atas keberhasilannya menjadi dokter, lalu mereka saling memberi salam dengan membungkukkan badan dengan posisi duduk.

\section{Analisis}

Pada tuturan data (2) terdapat kata "omedetou” kata tersebut merupakan bentuk informal dari kata "omedetou gozaimasu" yang dalam Kokugojiten (https://www.weblio.jp/content/\%E3\%81\%8A\%E3\%82\%81\%E3\%81\%A7\%E3\%81 \%A8\%Е3\%81\%86\%Е5\%BE\%A1\%Е5\%BA\%A7\%Е3\%81\%84\%Е3\%81\%BE\%Е3\% 81\%99) berarti 相手にとって喜ばしい出来事を祝福する表現。慶賀を表明する 言葉 (aite ni totte yorokobashii dekigoto wo shukufuku suru hyougen. Keiga wo hyoumei suru kotoba) yaitu sebuah ekspresi yang mengungkapkan kegembiraan atas peristiwa bahagia atau keberhasilan orang lain.

Tuturan (2) “omedetou” yang dituturkan oleh Jiroo dengan perasaan senang menunjukkan bahwa penutur mengakui kemampuan petutur, sehingga tuturan tersebut termasuk pujian secara tidak langsung dengan bentuk pujian pleasing.

\section{2) Pujian Terikat}

a) Pujian Langsung + Tidak Langsung Admiration

\section{Pada Topik Pujian Kepemilikan Barang}

Data $3(00.49 .27-00.49 .32)$

Honjo (3.1)： すごいな

"sugoi na"

'Luar biasa ya'

Jiroo ：うん見事だ

"un migoto da"

'Ya, Fantastik'

Honjo (3.2) ：ドイツ工業技術の結晶だ

"doitsu kougyougijutsu no kesshou da"

'Sebuah kemenangan teknologi industri Jerman' 


\section{Konteks Data 3}

Partisipan dalam data 3 terjadi antara Honjo sebagai penutur pujian yang juga seorang Insinyur. Petutur tidak langsung Jiroo dan negara Jerman. Hubungan antara Honjo dengan Jerman adalah pengagum dengan negara yang dikagumi. Percakapan terjadi pada siang hari saat kunjungan insinyur-insinyur Jepang ke pabrik pesawat di Jerman. Percakapan terjadi di dalam pesawat buatan Jerman yang sedang terbang. Semua insinyur dari Jepang yang melakukan pengamatan berada di dalam pesawat. Jiroo dan Honjo termasuk peserta kunjungan pabrik. Saat Jiroo dan Honjo diizinkan oleh pihak Jerman mengelilingi dalam badan pesawat. Jiroo dan Honjo sangat kagum melihat pesawat tersebut.

\section{Analisis}

Pada tuturan (3.1) Honjo menuturkan pujian secara langsung atas pesawat milik Jerman . Tuturan "sugoi na" terdapat kata "sugoi" yang dalam kokugojiten (https://www.weblio.jp/content/\%E3\%81\%99\%E3\%81\%94\%E3\% 81\%84) 恐ろしい ほどすぐれている。ぞっとするほどすばらしい。(Osoroshii hodo sugurete iru. Zotto suru hodo subarashii) bermakna sesuatu yang luar biasa hebat. Akhiran “-na” dalam tuturan memiliki arti menegaskan. Sehingga tuturan (3.1) termasuk kedalam pujian secara langsung karena terdapat kata evaluatif positif yang diucapkan dengan ekspresi muka kagum yang menegaskan kepimilikan barang yang luar biasa.

Pada tuturan (3.2) Honjo menuturkan pujian secara tidak langsung dengan mengagumi teknologi Jerman terdapat pada kalimat "doitsu kougyougijutsu no kesshou da", kalimat tersebut termasuk pujiian tidak langsung bentuk Admiration karena kalimat tersebut memiliki makna menetapkan Jerman sebagai target pembelajaran sebagai negara yang dikagumi atas kehebatan teknologi yang dimiliki.

\section{b) Pujian Langsung + Tidak Langsung Appreciation}

\section{Pada Topik Pujian Terhadap Kepemilikan Barang}

Data $4(01.58 .40-01.58 .52)$

Angkatan udara (4.1)：すばらしい飛行機です

"subarashii hikouki desu,"

'pesawat yang luar biasa,' 
Nimatul Maulida, Tindak Tutur Memuji dalam Film Kaze Tachinu

$$
\begin{aligned}
& \text { ありがとう } \\
& \text { “arigatou” } \\
& \text { 'Terimakasih’ }
\end{aligned}
$$

\section{Konteks Data 4}

Partisipan dalam data 4 terjadi antara Pilot dari angkatan udara sebagai penutur, dan Jiroo sebagai petutur. Hubungan antara Pilot dari angkatan udara dengan Jiroo adalah klien dengan Insinyur pesawat yang menciptakan pesawat pesanan dari klien. Percakapan terjadi pada pagi hari di lapangan terbang sedang menguji pesawat pesanan Angkatan udara yang dibuat oleh Jiroo. Suasana hati semua orang yang ada di lapangan terbang sedang bahagia menanti keberhasilan terbangnya pesawat. Setelah pesawat mendarat, Pilot dari angkatan Udara berjalan mendekati Jiroo dan mengulurkan tangan untuk memberi selamat atas hasil pesawat yang dapat terbang dari hasil rancangan Jiroo

\section{Analisis}

Pada data (4.1) terdapat kata "subarashii" dalam kokugojiten (https://www.weblio.jp/content/\%E3\%81\%99\%E3\%81\%B0\%E3\%82\%89\%E3\%81\% 97\%E3\%81\%84) 思わず簡単するようなさまを表す (omowazu kantan suru youna sama wo arawasu) yaitu kata untuk mengungkapkan kekaguman yang luar biasa. Kata "subarashii" dalam tuturan (4.1) menyatakan kekaguman penutur atas pesawat buatan dari petutur, sehingga tuturan tersebut termasuk bentuk tuturan langsung karena terdapat penanda evaluatif positif "subarashii" dan juga termasuk kata sifat i.

Sedangkan pada data (13.2) terdapat kata "arigatou” dalam Kokugojiten (https://www.weblio.jp/content/\%E3\%81\%82\%E3\%82\%8A\%E3\%81\%8C\%E3\%81 \%A8\%E3\%81\%86) 感謝の気持ちを表す言葉 ”kansha no kimochi wo arawasu kotoba" yaitu sebuah kata yang mengungkapkan rasa terima kasih. tuturan terima kasih diucapkan karena penutur menyatakan pengakuan atas kontribusi penutur dalam hal pembuatan pesawat yang luar biasa. Sehingga tuturan (4.2) termasuk bentuk tuturan pujian Appreciation. 


\section{c) Pujian Tidak Langsung Pleasing + Tidak Langsung Request}

\section{Pada Topik Pujian Terhadap Kepribadian}

Data $5(00.29 .53-00.29 .58)$

Jiroo：正月に帰るからお父さんに話してあげるよ

"shougatsu ni kaeru kara otou san ni hanashite ageru yo"

'aku akan bicara pada ayah saat pulang nanti'

Kayo (5)：嬉しいお願いね

"ureshii onegai ne"

'Asyik, tolong ya'

\section{Konteks Data 5}

Partisipan dalam data 5 terjadi antara Kayo dan Jiroo. Mereka adalah adik dan kakak yang akrab. Percakapan tersebut terjadi pada malam hari di atas perahu saat Jiroo akan mengantar pulang adiknya yang bernama Kayo sampai ke stasiun. Jiroo mengantarkan adik perempuannya yang bernama Kayo menuju stasiun dan menyertai dengan ikut naik perahu. Kayo mengunjungi Jiroo yang merantau untuk menuntut ilmu dan tinggal di Tokyo. Saat di perahu terjadi percakapan antara Kayo dengan Jiroo. Kayo menyatakan ingin melanjutkan ke universitas dan belajar ilmu kedokteran. Jiroo pun menanggapi bahwa dirinya akan berusaha berbicara dengan ayah mereka untuk mengizinkan Kayo menuntut ilmu sesuai dengan bidang yang diinginkan. Kayo yang mendengar tanggapan Jiroo merasa senang

\section{Analisis}

Pada tuturan (5) yang dituturkan oleh Kayo kepada Jiroo, "ureshii onegai ne" terdapat tuturan "ureshii". Dalam kokugojiten (https://www.weblio.jp/content/\%E3\%81\%86\%E3\%82\%8C\%E3\%81\%97\%E3\%81\% 84) 満足して、相手に感謝する気持ちになるさま。ありがたい。 (manzoku shite, aite ni kansha suru kimochi ni naru sama. Arigatai. kajikenai) memilik arti mengungkapkan rasa puas dan merasa bersyukur kepada orang lain, menghargainya. Tuturan (5) termasuk dalam kata interjeksi terdapat pada kata "ureshii". Kata interjeksi memiliki fungsi untuk menyatakan perasaan dari seseorang. Penutur mengucapkan "ureshii" karena ingin mengungkapkan perasaan berupa rasa terkesan dan rasa senang atas kebaikan hati petutur. 
Nimatul Maulida, Tindak Tutur Memuji dalam Film Kaze Tachinu

Pujian dalam tuturan "ureshii" termasuk ke dalam pujian yang dituturkan secara tidak langsung menggunakan bentuk pleasing. Penutur mengucapkan tuturan (5) karena merasa senang dan puas bahwa petutur bersedia membantu penutur untuk berbicara dengan orang tua penutur bahwa penutur ingin pergi ke universitas dan mengambil jurusan kedokteran. Kemudian pujian dalam tuturan (5) juga dituturkan secara tidak langsung, akan tetapi dituturkan dengan bentuk yang berbeda yaitu bentuk request. Pada tuturan (5) terdapat kata "onegai ne". Kata "negai" dalam kokugojiten

(https://www.weblio.jp/content/\%E3\%81\%AD\%E3\%81\%8C\%E3\%81\%84)こうな ってほしいと思う物事 (kounatte hoshii to omou mono goto) memiliki arti hal-hal yang saya inginkan terjadi. Tuturan "onegai ne" dituturkan karena penutur meminta sesuatu dari petutur, dan penutur tahu bahwa petutur lebih berpengalaman dalam hal meminta izin orang tua untuk keperluan sekolah di bidang yang diinginkan.

\section{d) Pujian Tidak langsung Knowing + Reward Offering dan Explanation}

\section{Pada Topik Pujian Terhadap Kemampuan}

Data $6(01.29 .39-01.28 .47)$

Kepala Insinyur Hattori (6.1) : 海軍の次の飛行機が来る、君がやるんだ

"kai gun no tsugi no hikouki ga kuru, kimi ga yarunda"

'Kompetisi desain Angkatan Laut berikutnya ada di tanganmu'

(6.2) 会社は全力できみを守る

"kaisha ha zenryoku de kimi wo mamoru

'Perusahaan akan melindungimu.'

(6.3)君が役に立つ人間である間はな

"kimi ga yaku ni tatsu ningen de aru aida ha na"

karena kau seseorang yang berguna'

\section{Konteks Data 6}

Partisipan dalam data 6 terjadi antara Kepala insinyur Hattori sebagai penutur, dan Jiroo sebagai petutur. Hubungan antara Kepala insinyur Hattori dengan Jiroo 
adalah atasan dengan bawahan. Percakapan tersebut terjadi pada malam hari di dalam mobil saat proses menyembunyikan Jiroo. Jiroo menyatakan ingin kembali ke apartemen yang ditinggali sebelumnya untuk mengambil surat yang diterima dari Naoko, tetapi Kepala Insinyur Hattori melarangnya kembali dengan menyatakan bahwa lebiih penting diri Jiroo daripada surat tersebut. Kepala Insinyur Hattori menyatakan pujian secara tidak langsung yang menunjukkan Jiroo sangat berguna dengan kemampuannya merancang desain pesawat. Kepala Insinyur Hattori menyatakan tuturan pujian tidak langsung dengan nada serius.

\section{Analisis}

Pada tuturan (6.1) Kepala Insinyur Hattori memuji secara tidak langsung kemampuan Jiroo, "kai gun no tsugi no hikouki ga kuru, kimi ga yarunda” memiliki arti 'Kompetisi desain Angkatan Laut berikutnya ada di tanganmu' merupakan tuturan pujian secara tidak langsung bentuk Knowing yang memiliki makna bahwa penutur memberi tahu keyakinan penutur mengagumi kemampuan yang dimiliki petutur untuk dapat memenuhi pekerjaan merancang pesawat di kompetisi desain yang akan diadakan oleh Angkatan Laut. Sedangkan dalam tuturan (6.2) "kaisha ha zenryoku de kimi wo mamoru” yang memiliki arti 'Perusahaan akan melindungimu', kalimat tersebut merupakan tuturan pujian bentuk Reward Offering yang dituturkan dengan cara penutur menawarkan imbalan kepada petutur, berdasarkan kontribusi merancang desain pesawat maka petutur berhak mendapat perlindungan dari pihak perusahaan sebagai tanda pujian telah berkonstribusi. Selanjutnya tuturan (6.3) "kimi ga yaku ni tatsu ningen de aru aida ha na" merupakan tambahan pujian dalam bentuk Explanation dengan menunjukkan petutur merupakan orang yang berguna karena kemampuannya merancang desain pesawat, jika petutur berniat ikut berkontribusi dalam penawaran pembuatan desain pesawat dalam kompetisi yang akan diadakan oleh Angkatan Laut, maka petutur akan dilindungi.

\section{e) Pujian Langsung + Tidak Langsung Explanation + Tidak Langsung Contrast}

\section{Pada Topik Pujian Kepemilikan Barang}


Nimatul Maulida, Tindak Tutur Memuji dalam Film Kaze Tachinu

Data $7(00.56 .13-00.56 .20)$

Kaproni : どうかね?

"douka ne"

'bagaimana menurutmu?'

JIroo (7.1)：壮大です

"soudai desu”

'Luar biasa'

(7.2) 古代ローマの建物のようです

“kodai Ro-ma no tatemono you desu”

'Seperti bangunan kuno Roma'

Kaproni ：まあ当局のハックリ好きにつけ込んだんだ

"maa toukyoku no hakkuri suki ni tsukekondanda"

'Pesawat ini terlalu besar untuk digunakan dalam perang'

こんなものは戦争には使えんよ

"konna mono ha sensou ni ha tsukaen yo"

'tapi Angkatan Udara suka hal yang besar'

Jiroo (7.3)：私たちの国は貧乏です

"watashi tachi no kuni ha binbou desu"

Negaraku miskin dan tertinggal jauh'

技術も未熟でとてもこれだけのものは作れません

"gijutsu mo mijikude totemo kore dake no mono ha tsukuremasen"

'kita tidak pernah dapat membuat hal seperti ini'

\section{Konteks Data 7}

Partisipan dalam data 7 terjadi antara Jiroo sebagai penutur, Kaproni sebagai petutur. Hubungan antara Jiroo dengan Kaproni adalah pengagum dengan orang yang dikagumi. Percakapan ini terjadi di dalam mimpi Jiroo yang bertemu dengan Kaproni. Jiroo bermimpi melihat pesawat buatan Kaproni yang baru. Jiroo merasa kagum ketika melihat dan merasakan menumpangi pesawat tersebut. Jiroo mengutarakan kekagumannya atas barang milik Kaproni yang merupakan seseorang yang menjadi 
inspirasi Jiroo dalam hal cita-cita sebagai insinyur pesawat, Kaproni menanggapi pujian Jiroo dengan merendah dan memberi motivasi kepada Jiroo.

\section{Analisis}

Pada tuturan (7.1) Jiroo memberikan pujian secara langsung, "soudai desu" terdapat kata "soudai" dalam kamus kokugojiten (https://www.weblio.jp/content/\%E3\%81\%9D\%E3\%81\%86\%E3\%81\%A0\%E3\%81 \%84) yaitu 大きく立派なこと（ookiku rippana koto） yang memiliki arti hal yang besar dan hebat. Dari penjabaran arti soudai tuturan percakapan tersebut merupakan tuturan langsung memuji kepemilikan barang seseorang, dalam percakapan (7.1) penutur memuji pesawat hasil buatan petutur. Dalam tuturan (7.2) Jiroo menuturkan pujian secara tidak langsung dengan menjelaskan bentuk pesawat, "kodai Ro-ma no tatemono you desu” merupakan tuturan pujian tidak langsung bentuk Explanation yang menerangkan aspek-aspek positif dari pujian sebelumnya yaitu memuji pesawat yang besar dan megah seperti bangunan Roma kuno. Sedangkan dalam tuturan (7.3) Jiroo mengungkapkan pujian secara tidak langsung dengan membandingkan, sehingga termasuk dalam pujian tidak langsung bentuk Contrast dengan adanya kalimat tuturan "watashi tachi no kuni ha binbou desu. gijutsu mo mijikude totemo kore dake no mono ha tsukuremasen" yang berarti "Negaraku miskin dan tertinggal jauh, kita tidak pernah dapat membuat hal seperti ini' secara tidak langsung kalimat tersebut menjadikan petutur lebih menonjol dengan memandingkan sesuatu dari milik penutur.

\section{f) Pujian Langsung + Tidak Langsung Surprise + Tidak Langsung Assumption}

Data $8(00.05 .58$ - 00.06.06)

Ibu Jiroo(8)：㐫勇ましい姿ですね

"Maa isamashii sugata desune"

'Wah pemberani ya'

Jiroo

: うっかりして転びました

"ukkarishite korobimashita"

'ini karena ceroboh lalu tergelincir' 
Nimatul Maulida, Tindak Tutur Memuji dalam Film Kaze Tachinu

Ibu Jiroo ：けんかはなりませんよ

"kenka ha narimasenyo"

'jangan berkelahi lo’

Jiroo : はい

"hai"

'baik'

\section{Konteks Data 8}

Parisipan dalam data 8 terjadi antara Ibu jiroo dengan Jiroo. Mereka adalah ibu dan anak. Percakapan terjadi pada siang hari di rumah Jiroo saat Jiroo pulang ke rumah dan menemui Ibunya. Sebelumnya Jiroo pergi ke kota untuk meminjam majalah tentang pesawat, setelah meninggalkan tempat meminjam majalah, Jiroo melewati jalan yang terdapat anak kecil yang sedang dibully oleh orang yang seumuran dengan Jiroo. Jiroo membantu membela anak kecil tersebut dan terjadi dorong mendorong antara Jiroo dengan si pembully, sehingga pakaian dan wajah Jiroo kotor terkena tanah. Ibu Jiroo sebagai penutur, dan juga seorang ibu bagi petutur. Sebenarnya ibu Jiroo mengetahui bahwa Jiroo telah bertengkar dengan seseorang sehingga ibu Jiroo melarang Jiroo untuk bertengkar, tetapi Jiroo menyangkal dengan mengatakan bahwa dirinya hanya jatuh bukan bertengkar

\section{Analisis}

Pada tuturan (8) yang dituturkan oleh ibu Jiroo terdapat penanda gramatikal yang menandakan bahwa tuturan (8) termasuk ke dalam kategori memuji, hal ini dapat dilihat pada kata "maa" yang dalam kokugojiten (https://www.weblio.jp/content/\%E3\%81\%BE\%E3\%81\%82) 驚いたり感心したり したときに発する語。多くの情勢が用いる (odoroi tari kanshin shitari shita toki ni hassuru go. Ookuno jousei ga mochiiru) merupakan sebuah kata yang terpancar saat terkejut atau terkesan, dan banyak wanita yang menggunakan kata tersebut. Pada tuturan tersebut, penutur terkejut dengan penampilan petutur yang pertama kali ditemui saat pulang kerumah dengan tuturan "maa" .

Sedangkan kata "isamashii" dalam kokugojiten (https://www.weblio.jp/content/\%E3\%81\%84\%E3\%81\%95\%E3\%81\%BE\%E3\%81 
\%97\%E3\%81\%84) 危険や困難を恐れず、積極的に事を行うさま (kiken ya kon'nan wo osorezu, sekkyokuteni koto wo okonau sama) yang memiliki makna berani ; tidak takut akan bahaya atau kesulitan, bertindaklah positif, termasuk dalam kata sifat i. Kata "isamashii" lalu diikuti kata "sugata" yang dalam kokugojiten(https://www.weblio.jp/content/\%E3\%81\%99\%E3\%81\%8C\%E3\%81\%9

F）外観からとらえた体の格好 (gaikan kara toraeta karada no kakkou) yang memiliki arti penampilan tubuh yang tampak. Kata "sugata" digunakan penutur untuk menekankan pada penampilan petutur, sehingga pada konteks kata "isamashii sugata" bisa diartikan tampak berani hanya dari tampilan, bukan dari sisi kepribadian.

Tuturan (8) dituturkan secara tidak langsung yaitu bentuk surprise dengan menggunakan kata "maa” setelah melihat petutur secara langsung, yang terdapat banyak noda tanah pada pakaian dan juga wajah. Sedangkan tuturan (8) merupakan tuturan pujian secara langsung + tidak langsung bentuk assumption. Kata "isamashii" sebagai penanda evalutif positif yang dapat dimasukkan dalam kategori pujian langsung. Pujian tidak langsung assumption dikarenakan kata "isamashii sugata" yang digunakan penutur mengungkapkan keterkejutan ketika melihat penampilan petutur yang berantakan, yang kemudian konteks penampilan berantakan diasumsikan sebagai sebab dari perkelahian, sehingga secara langsung dikatakan pemberani. Sehingga tuturan (8) mengandung pujian langsung + pujian tidak langsung surprise + assumption.

\section{SIMPULAN}

Setelah melakukan penelitian dalam tuturan pujian film Kaze Tachinu terdapat tuturan pujian yang dituturkan secara terikat dan tuturan pujian yang dituturkan secara tidak terikat. Pada bagian tuturan pujian tidak terikat didapatkan dua tipe pujian yaitu pujian secara langsung dan pujian secara tidak langsung. Pujian langsung dan pujian tidak langsung ditemukan pada tiap-tiap topik pujian, yaitu topik pujian terhadap kemampuan, kepemilikan barang, penampilan, dan kepribadian.

Pada pujian terikat ditemukan berbagai keterikatan antara pujian langsung dengan pujian tidak langsung. Pada topik memuji terhadap kemampuan ditemukan 5 
Nimatul Maulida, Tindak Tutur Memuji dalam Film Kaze Tachinu

buah yaitu pujian tidak langsung surprise + pujian tidak langsung evaluation, pujian tidak langsung explanation + pujian langsung, pujian langsung + pujian tidak langsung explanation, pujian langsung + pujian tidak langsung knowing, dan pujian tidak langsung knowing + pujian tidak langsung reward offering. Pada topik pujian terhadap benda milik orang lain/ kepemilikan barang ditemukan 4 buah yaitu pujian langsung + pujian tidak langsung surprise, pujian langsung + pujian tidak langsung explanation + contrast, pujian langsung + tidak langsung admiration, dan pujian langsung + pujian tidak langsung appreciation. Pada topik pujian terhadap penampilan ditemukan 2 buah yaitu keterikatan antara pujian langsung + pujian tidak langsung surprise + assumption dan pujian langsung + pujian tidak langsung surprise. Sedangkan pada topik pujian terhadap kepribadian/keramahan ditemukan 2 buah yaitu keterikatan antara pujian, pujian tidak langsung pleasing + request, dan pujian langsung + pujian tidak langsung explanation.

Dari hasil penelitian tersebut, mayoritas tindak tutur pujian yang ditemukan dalam film Kaze Tachinu menggunakan pujian secara langsung, dikarenakan film tersebut hasil karya orang Jepang dan tokoh dalam film juga menggunakan bahasa Jepang sebagian besar menggunakan kata sifat. Tuturan langsung yang muncul pada pujian terhadap kemampuan seseorang ditemukan kata "kirei" yang berarti indah, "soudai" yang berarti luar biasa, "kanpeki" yang berarti sempurna, dan kata "ii" yang berarti baik. Pujian terhadap kepemilikan barang ditemukan kata "kenjitsu" yang berarti kuat, dan beberapa kata yang berarti luar biasa yaitu "migoto", "soudai", "sugoi", dan "subarashii". Pada pujian terhadap penampilan ditemukan kata "kirei" yang berarti cantik, "kawaii" yang berarti imut" dan "isamashii" yang berarti berani. Pada pujian terhadap kepribadian ditemukan kata "rippa" yang berarti bermartabat, "nesshin" yang berarti sungguh-sungguh, dan kata "kira-kira" yang berarti cerah.

\section{DAFTAR PUSTAKA}

Holmes, J. (1986). "Compliments and Compliment Responses in New Zealand English". Anthropological Linguistics, Vol. 28, No 4 (Winter, 1986), 485-508. 
Indiana: The Trustees of Indiana University on behalf of Anthropological Linguistics.

Huang, Yi-Chi dan Ming-Yu Tseng. (2014). Compliment Paying Strategies In Taiwan Mandarin: The Role Of Interlocutor's Status. Master Thesis. Tidak diterbitkan. National Sun Yat-sen University.

Leech, G. (1993). Prinsip - Prinsip Pragmatik. (Diterjemahkan oleh Dr. M.D.D Oka). Jakarta: Penerbit Universitas Indonesia (UI-PRESS).

Saifudin, Akhmad. (2005). Faktor Sosial Budaya dan Kesopanan Orang Jepang dalam Pengungkapan Tindak Tutur Terima Kasih pada Skenario Drama Televisi Beautiful Life Karya Kitagawa Eriko. Tesis. Pascasarjana UI.

Saifudin, Akhmad, Aryanto, Bayu, \& Budi, Iwan Setiya. (2008). Analisis Fungsi Pragmatik Tindak Tutur Pertanyaan dalam Percakapan Bahasa Jepang antara Wisatawan Jepang dan Pemandu Wisata Indonesia di Candi Borobudur. Lite, 4(1), 8-15. http://doi.org/10.5281/zenodo.2636103

Saifudin, Akhmad. (2010). Analisis Pragmatik Variasi Kesantunan Tindak Tutur Terima Kasih Bahasa Jepang dalam Film Beautiful Life Karya Kitagawa Eriko. Lite, 6(2), 172-181. http://doi.org/10.5281/zenodo.2631226

Saifudin, Akhmad. (2018). Konteks dalam Studi Linguistik Pragmatik. LITE, 14(2), 108-117. http://doi.org/10.5281/zenodo.2631204

Yuan, Yi. (2002). Compliments And Compliment Responses In Kuming Chinese. Journal of International Pragmatics Assosiation. Pragmatics 12:2. 183-226.

Yule, G. (2014). Pragmatik. (Diterjemahkan oleh Indah Fajar Wahyuni). Yogyakarta: Pustaka Pelajar.

https://www.weblio.jp/content/ (diakses pada 20 Januari 2019) 